\title{
A Comparative Study of the Community Construction Mode in Fujian and Taiwan*
}

\author{
Zhixiong Huang \\ Xiamen Academy of Arts and Design \\ Fuzhou University \\ Xiamen, China
}

\author{
Yamin Zhang \\ Xiamen Academy of Arts and Design \\ Fuzhou University \\ Xiamen, China
}

\begin{abstract}
This paper, using the method of multi-case study, takes cultural creativity as the starting point, introduces the methods and theories of design thinking, and selects the successful typical cases of communities construction in Fujian and Taiwan to analyze the key rules and practices at the different stages of community construction from the aspects of motivation, resources, problems and solutions. The general rules of the community construction of Fujian and Taiwan are summarized. Through the comparative study of the rules of Fujian and Taiwan community construction, the construction model of communities in Fujian and Taiwan driven by cultural creative design and the experience and enlightenment worth learning are inferred to contribute to the sustainable development of communities in Fujian Province, and provide some exploration experience for the study of the theoretical system of the current communities.
\end{abstract}

Keywords-community construction; Fujian and Taiwan; model comparison; cultural creative design

\section{INTRODUCTION}

As early as October 2005, the government of China put forward specific requirements for the construction of a new countryside: "development of production, ample life, civilized villages, clean villages, and democratic management." In 2013, for the first time the No. 1 Document of the Central Committee proposed the goal of building a "beautiful village", which is the "upgraded version" of the new rural construction. Whether it is the "beautiful China" at the national level, the "beautiful village construction" in Fujian Province or the "Joint Creation of Beautiful Xiamen" in Xiamen, all parts of China are actively exploring new construction models. At present, the construction model of community renewal driven by cultural creative design by using design thinking is getting more and more attention of all walks of life. As an area that conducted communities construction earlier in China, Taiwan has incorporated the cultural and creative industries in it from the experience of "Work Program of Community Development" to the introduction of the "Japanese Village-Building Movement", which has achieved the "overall construction of community" model in Taiwan.

After more than 20 years development of community construction in Taiwan, the material and space environment of the community has been optimized, the local characteristic industry has been revitalized and cultural and artistic activities have been extended to all aspects of life, so the living quality of residents has been improved. Because of the close relationship between "geography, blood, literature, business, and law", Fujian and Taiwan have formed similar regional cultural connotations and values. Therefore, their experience and practice in cultural creativity and community construction are worthy of comparative study, as shown in "Fig. 1".
*Fund Project: 2016 Social Science Planning Project of Fujian Province: Research on the Construction Model of Fujian and Taiwan Community Driven by Cultural Creative Design (FJ2016B215) 


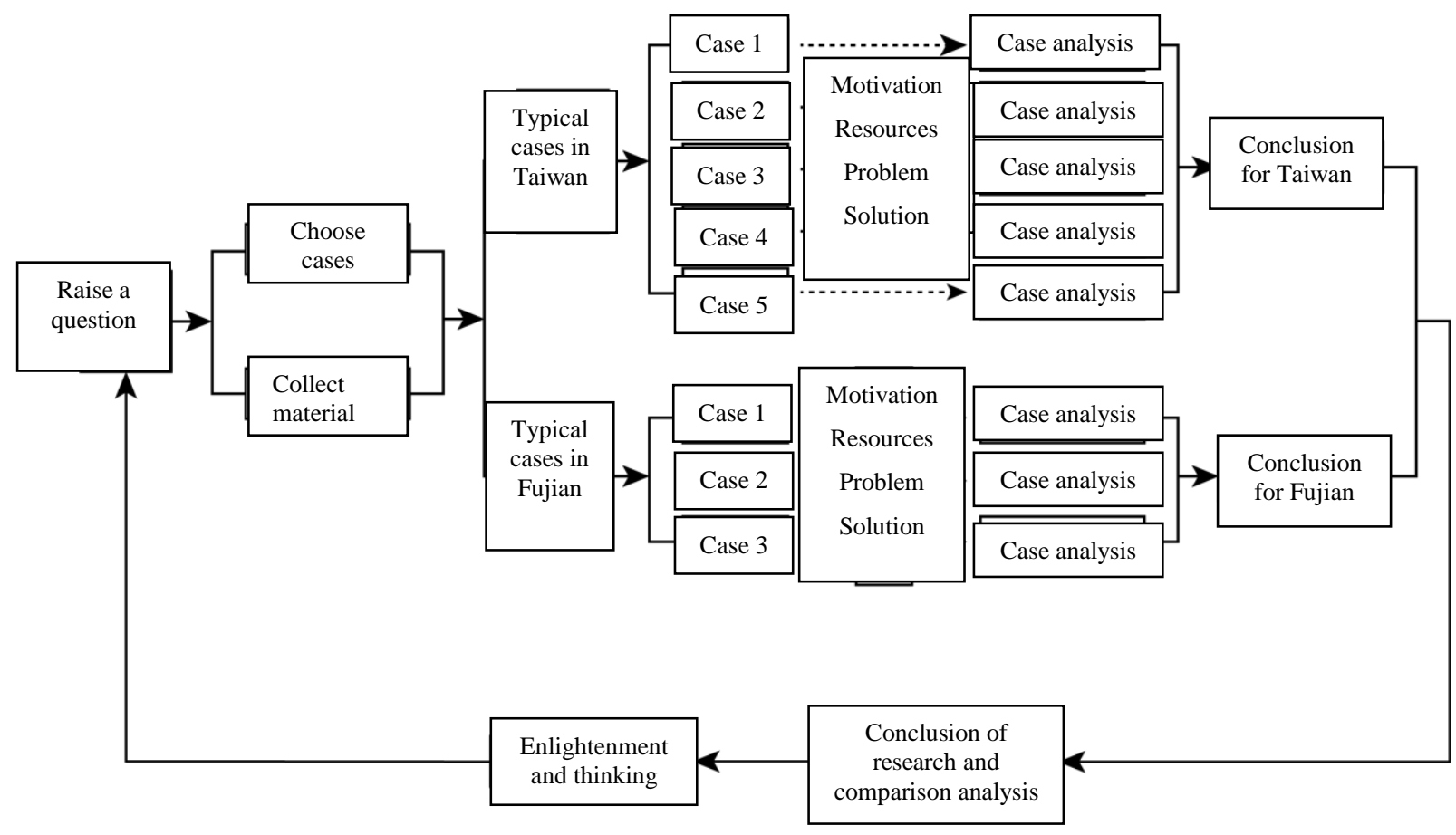

Fig. 1. Framework of research idea.

\section{ANALYSIS OF TYPICAL CASE OF COMMUNITY CONSTRUCTION IN FUJIAN AND TAIWAN}

The community construction in Taiwan has been developed for more than 20 years. Each community has different life culture themes, which can be roughly divided into five different types: ecological community, art community, traditional cultural community, leisure agriculture community and industrial community. The sampling types of Taiwan community construction cases in this study are also based on these five types, which are located in Tainan, Taichung, and Taipei regions. They can basically reflect the situation of Taiwan community construction. And then the author selects a typical case from each community type and analyzes from the motivation, resources, problems, and solutions.

The community construction in Fujian Province is still in the exploration stage, both in theoretical research and practical activities. However, as a province that introduced the urban construction outline earlier in Chinay, Fujian also combines the advantages of various regions in the process of innovative social governance to vigorously promote the reform and innovation of the institutional mechanisms of social governance [1]. Fujian Province has the advantages of cultural industry resources. This study selects the communities in three central cities of Fujian Province, including Three Lanes and Seven Alleys in Fuzhou, Zeng Cuo An Community in Xiamen and 5 communities in Quanzhou as the typical cases of community construction in Fujian Province to analyze.

\section{A. Analysis of Typical Cases of Community Construction in Taiwan}

1) Ecological community - Taomi community: An ecological community refers to a community rich in ecological resources such as background forests, waters, grasslands, animals and plants.

Taomi Community, located about 5 kilometers southwest of Puli Town, Nantou County, Taiwan, covers an area of 18 square kilometers with a population of about 1,200 people and the altitude of 420-800 meters above sea level, which was formerly known as "Taomili". Before the September 21 earthquake, Taomili was similar to the rural areas in mainland China today, which was a poor and backward traditional rural area. Because of the pace of industrialization and urbanization, the young and middle-aged labor force in Taomi left there, so it became an old community with an aging population structure and recessionary agricultural economy. In the "September 21" earthquake in 1999, the Taomi community was seriously damaged. It was also an opportunity for Taimi to link up the residents to successfully transform the edge community with a chaotic environment, experienced earthquake disasters, and weak development to an ecological community that integrates cultural creativity, organic agriculture, and ecological conservation by taking the "ecological community construction" as the direction with the assistance of all parties in Taiwan.

During the post-disaster community construction process, the residents of the Taomi community quickly reached a consensus to rely on the rich local ecological resources, establish the direction with eco-tourism as an industry, promote the tourism industry with the concept of ecological community, and use this as the cornerstone of community 
development. They establish the "Green Dream Corps" to popularize and promote ecological education and training; through the inspiration and training of professional teams, they transform the values of community residents, let residents re-recognize themselves and the environment around them, and awaken community residents' cultural consciousness of the ecology, environmental protection and nature to master professional skills, and actively contribute to the home construction. They incorporate cultural and creative design elements to refine the new cultural symbol of Taomi community - "Frog Republic"; there are 29 species of frogs in Taiwan, and Taomi has 23 species; there are totally 143 species of dragonfly, and 49 are in Taomi, which accounts for about one-third of the dragonfly species in Taiwan; in Taomi, from the sculptures and patterns of frogs to the wetland parks and ecological pools in the courtyards of the houses, ecological homes are created for frogs everywhere. They create a landmark building - "Paper Church"; it is designed by the famous Japanese architect Banmao for the collapsed Eagle Church. The paper church is made of steel, wood and paper, which shows Taomi people's strong living spirit and improves the humanity ecological landscape of community and when promoting the development of the lodging industry, tourism and catering industry. It provides employment opportunities for community residents as well as achieves good economic benefits. This kind of community development model oriented by eco-tourism with direct participation of residents makes Taomi a "worldly paradise" favored by tourists as shown in "Table II".

TABLE I. ANALYSIS OF TAOMI COMMUNITY CONSTRUCTION

\begin{tabular}{|c|c|c|c|c|}
\hline $\begin{array}{l}\text { The name of } \\
\text { community }\end{array}$ & Motivation & Resource & Problems & Solution \\
\hline $\begin{array}{l}\text { taomi } \\
\text { Community }\end{array}$ & $\begin{array}{l}\text { The September } \\
21 \text { earthquake }\end{array}$ & $\begin{array}{l}\text { 1. government and } \\
\text { NGO organization } \\
\text { 2.Earthquake } \\
\text { memorial hall } \\
\text { 3. Rich ecological } \\
\text { resources } \\
\text { 4.agricultural } \\
\text { resources }\end{array}$ & $\begin{array}{l}\text { 1.The aging population } \\
\text { structure and recessionary } \\
\text { agricultural economy; } \\
\text { 2.The loss of young and } \\
\text { middle-aged labor; } \\
\text { 3.Low participation of } \\
\text { residents; communication } \\
\text { 4.Poor } \\
\text { between organizations; } \\
\text { 5.The interests of all parties; }\end{array}$ & $\begin{array}{l}\text { 1.Establish the direction of } \\
\text { ecological community } \\
\text { construction; } \\
\text { 2.Awaken the consensus and } \\
\text { strengthen the identity; } \\
\text { 3.use cultural creativity to } \\
\text { help to refine cultural symbols; } \\
\text { 4.Start with a small-scale } \\
\text { transformation; }\end{array}$ \\
\hline
\end{tabular}

2) Art community - Monster Village: An art community is a new community model that integrates art with local communities and makes innovation and upgrading.

The Monster Village, located in Xitou Village, Nantou County, was originally a small business district planned by the "Xitou Mingshan Shenlin Club". Because of its beautiful geographical environment, it was once a leisure resort for young people to honeymoon. However, due to the September 21 earthquake, the original honeymoon holiday industry was greatly affected. Although it has been repaired, it can no longer see the prosperous scene in the past. In order to revitalize the regional economy, Monster Village has determined its target audience as young people, and used animation creation and derivative development as means, hoping to revitalize the community through community construction.

The Monster Village was originally a small mountain village without special cultural resources. In the early stage of the community construction, Mr. Lin Zhiying, the general manager of Mingshan Shenlin Club, extracted the "monster culture" from his grandfather's legend and carry out community construction with the monster culture as the feature of community. According to the legend of Lin's grandfather, Mr. Lin Zhiying extracted the two animal images of "Kuma" and "Badou" and defined it as the cultural symbol of the community. Because the word "monster" broke through the people's conventional understanding of tourist attractions, the monster village seized people's eyes in the first time. On the basis of attracting people's attention, they made "KUSO funny and cute" personalized positioning of the word "monster". The "monster" of the monster village is not a horrible monster, but a funny, whimsical, and cute monster that fully caters to the young people's preference. Based on the constant exploration and development of monster culture and image, funny KUSO cultural creativity was used in various traditional industries, and realized the cultural industrialization transformation of cultural snack industry, cultural gift industry and cultural hotel industry, forming a business district with unique style that integrates commercial street, hotel, restaurant, shop, and supporting entertainment.

From the excavation of monster cultural resources, symbolization of monster culture, cultural industrialization management, and the creation of monster cultural business district to the formation of cultural creative community under the joint action, the monster village gradually become a new cultural creative community well-known in Taiwan relying on the insignificant "monster legend" culture that appears in the small area of the village as shown in "Table II". [2] 
TABLE II. ANALYSIS OF COMMUNITY CONSTRUCTION IN THE MONSTER VILLAGE

\begin{tabular}{|c|c|c|c|c|}
\hline $\begin{array}{l}\text { The name of } \\
\text { community }\end{array}$ & Motivation & resources & problem & solution \\
\hline $\begin{array}{l}\text { Monster } \\
\text { Village }\end{array}$ & $\begin{array}{l}\text { The September } \\
21 \text { earthquake }\end{array}$ & $\begin{array}{l}\text { 1. General } r \text { Manager } \\
\text { and his team of } \\
\text { Mingshan Shenlin } \\
\text { Club; } \\
\text { 2. Beautiful ecological } \\
\text { resources; } \\
\text { 3. "Monster Legend" } \\
\text { culture; }\end{array}$ & $\begin{array}{l}\text { 1. The huge impact of the } \\
9 \cdot 21 \text { earthquake; } \\
\text { 2. The characteristics of } \\
\text { cultural resources are not } \\
\text { prominent; } \\
\text { 3. The lack of professional } \\
\text { talents; }\end{array}$ & $\begin{array}{l}\text { 1. Excavation of the monster } \\
\text { legend cultural resources } \\
\text { 2. Cultural symbolization; } \\
\text { 3. Cultural industrialization; } \\
\text { 4. Business circle; } \\
\text { 5. communitization; }\end{array}$ \\
\hline
\end{tabular}

3) Traditional cultural community - Daxi Old Street: Traditional cultural communities are physical cultural resources and non-physical cultural resources including ancient buildings, ancient trees, folk crafts, folk customs, and traditional life scenes.

Daxi Town, where Daxi Old Street is located, is situated next to Dahan River in Taoyuan County, Taipei City. It has been an important inland port of Taiwan since the Ming and Qing Dynasties. The completion of the Taoyuan Dam has caused the decline of the Daxi waterway that has been in full flourish for a period. The improvement of land transportation conditions has made Daxi Town a new transportation hub. Daxi also seized the opportunity to rebuild the old streets and develop the tourism industry. In 2012, it was evaluated as one of the top ten sightseeing towns in Taiwan.

Daxi Old Street includes three main historical streets, including Heping Road, Zhongshan Road and Central Road. The overall community construction policy promoted by the "Cultural Construction Association" in the 1990s is a rare opportunity for the revitalization of Daxi Old Street. The unique historical heritage resources have become the most important capital for community construction. The initial update and protection concept was mainly promoted by the Caodianwei studio with teachers and students of architecture department in the university to stimulate the residents' feelings for the old street. Thus they spontaneously form a "historical neighborhood reconstruction committee" to participate in the renewal process of the historical block; they jointly formulate the "Life Space Beautification Project" plan and invite professional planners to protect and repair the historical and cultural resources of the old street and maintain the original natural ecological pattern by protecting the original ancient roads, reconstructing the street facade, repairing the archway, planning the road traffic, separating people and vehicles, and repairing cultural relics and historical buildings; they also create a commercial street and cultivate local specialty industries - wooden furniture and traditional dried tofu in addition to taking the historical heritage culture as a development focus to construct the wooden art ecological museum. Daxi Old Street makes the construction theme back to the residents. With the selforganizing power of the community as the leading factor, it encourages the people to participate in the transformation and renewal of the community in the form of gradual promotion activities and strengthens the community awareness. The improvement of material space environment, the preservation of cultural relics, the inheritance and development of characteristic industries, and the prosperity of Daxi Old Street have made the economy recover, the cultural atmosphere become strong, and the community continue to develop healthily as shown in "Table III".

TABLE III. ANALYSIS OF THE CONSTRUCTION OF DAXI OLD STREET COMMUNITY

\begin{tabular}{|c|c|c|c|c|}
\hline $\begin{array}{l}\text { The name of } \\
\text { community }\end{array}$ & Motivation & Resources & Problem & Solution \\
\hline $\begin{array}{ll}\text { Daxi } & \text { Old } \\
\text { Street } & \end{array}$ & $\begin{array}{l}\text { Beautify } \\
\text { living space }\end{array}$ & $\begin{array}{l}\text { 1. government and NGO } \\
\text { and NPO organization } \\
\text { 2. Professional planner; } \\
\text { 3. historical and cultural } \\
\text { heritage of Old street and } \\
\text { street houses; } \\
\text { 4. Wooden furniture and } \\
\text { traditional dried tofu } \\
\text { industry; }\end{array}$ & $\begin{array}{l}\text { 1.New and old street } \\
\text { integration; } \\
\text { 2.Coordination of the } \\
\text { interests of all parties; } \\
\text { 3.Poor communication } \\
\text { between organizations; } \\
\text { 4.Indifference to } \\
\text { historical architectural } \\
\text { culture; }\end{array}$ & $\begin{array}{l}\text { 1.Spontaneous formation of the } \\
\text { "Historical Street Reconstruction } \\
\text { Committee"; } \\
\text { 2.repair to Cultural relics and } \\
\text { historical buildings; } \\
\text { 3.Maintain the original ecological } \\
\text { pattern and protect the original ancient } \\
\text { road; } \\
\text { 4.Carry out road traffic planning, } \\
\text { separate people and vehicles; } \\
\text { 5. Create a commercial street; }\end{array}$ \\
\hline
\end{tabular}

4) Leisure agriculture community - Daya Community: The leisure agriculture community mainly refers to the community that combines agricultural landscape resources with agricultural production and develops new forms of agricultural production and management such as sightseeing, relaxation and tourism.
Located in the middle of Taichung City, Daya Community is blessed with natural conditions and a convenient water system that is ideal for the cultivation and growth of wheat. In 1995, the planting area of wheat in the Daya community was about 600 hectares, mainly providing raw material for the liquor-making enterprises. In 1996, the government stopped buying wheat. In 1998, there were only 20 hectares of wheat planting and Daya County fell into the 
dilemma until 2000 when Daya cooperate with Kinmen County. It supplies raw materials for the brewing of Jinmen sorghum wine, and then the wheat planting area is maintained at around 50 hectares. The ceramics workers of Daya community, based on their strong feelings towards the community, established Taichung County Painted Pottery Cultural Association in 2002 after seeing the decline of community due to the decline of traditional industry, hoping to promote the community construction work from a cultural perspective.

In response to the policy of "one village, one characteristic", the association regards wheat as the first choice for community characteristics. In addition to continuing the wheat contract with Jinmen County, it also develops peripheral products such as wheat noodles, wheat cakes, wheat handmade soap and ceramic products printed with wheat image, and integrates community resources to infiltrate wheat culture into the community's tourism, folklore, food, crafts, monuments, and agricultural specialties. They convey the community's endemic culture to the society and coagulate community consensus by holding Daya Wheat Culture Festival. [3] The community tourism driven by the wheat culture has created rich economic results for the community and has also driven the development of the ceramics industry. Daya Community is a model for the combination of traditional industries and distinctive cultures in Taiwan community construction work, as shown in "Table IV".

TABLE IV. ANALYSIS OF DAYA COMMUNITY CONSTRUCTION

\begin{tabular}{|c|c|c|c|c|}
\hline $\begin{array}{l}\text { The name of } \\
\text { community }\end{array}$ & Motivation & Resources & Problems & Solution \\
\hline $\begin{array}{l}\text { Daya } \\
\text { community }\end{array}$ & $\begin{array}{lr}\text { Promote } & \text { local } \\
\text { development } & \text { and } \\
\text { activate } & \text { Daya } \\
\text { economy } & \end{array}$ & $\begin{array}{l}\text { 1.Natural } \begin{array}{r}\text { conditions } \\
\text { suitable for wheat } \\
\text { growth; }\end{array} \\
\text { 2.Raw } \\
\text { suppliers; } \\
\text { 3. Wheat material } \\
\text { industry and painted } \\
\text { pottery craft industry; }\end{array}$ & $\begin{array}{l}\text { 1. High planting costs; } \\
\text { 2. decreasing planting } \\
\text { area; } \\
\text { 3. fallow; } \\
\text { 4. Lack of professional } \\
\text { talent; }\end{array}$ & $\begin{array}{l}\text { 1.Established "Taichung County } \\
\text { Painted Pottery } \\
\text { Association"; } \\
\text { 2.Use wheat as a specific industry } \\
\text { of the community; } \\
\text { 3.Develop wheat peripheral } \\
\text { products; } \\
\text { 4.Organize "Daya Wheat Culture } \\
\text { Festival"; } \\
\text { 5.Sustainable development of the } \\
\text { community; }\end{array}$ \\
\hline
\end{tabular}

5) Industrial type community - Bantou Community: Industrial type communities usually rely on local characteristic industries to drive local industry development and realize the industrial revitalization.

The Bantou Community is located in the northwest of Xingang Township, Chiayi County, Taiwan, with a population of about 700 people and an area of 4.5 square kilometers. Bantou Village has a five-point car railway of hundred-year sugar mill, which is the main passenger route when the road was not developed in the early days. It is also the common memory of the older generation of Bantou Village. Later, with the development of traffic, the five-point train was shut down and only the freight trains were reserved. In 1998, the Taiwan Sugar Railway was completely stopped The entry point for the community construction of Bantou Village is forming a "beautiful rural group" with scale effect through the integration of the cultural resources of the abandoned platform of the five-point Railway of the Tai Sugar Jiabei Line, and the combination of the three villages with historical origins including garden house of Gonghe County, Jiaozhi shear bond craft pavilion of Ban pottery kiln in Bantou village and Taohua campus in Nangang Village and connecting them through the abandoned five-point Railway of the Tai Sugar Jiabei Line.

Bantou Community is an example of industry-driven community construction. It promotes the development of cultural handicrafts with industry, uses local cultural resources, revitalizes local craft industry with cultural characteristics, and makes people participate in the community construction with the main line of reproducing artistic community and historical memory. They build a "station park" to induce the memory of Bantou people on the five-point railway, visually leading everyone into an art and historical space and triggering consensus; they use industry to promote the development of cultural handicrafts to realize industrial revitalization; shape the art village through the integration of resources and culture in the region.

The sponsors of Bantou Community discussed with several core figures how to make the art recreate the whole community. They will create Jiaozhi shear bond craft pavilion of Ban pottery kiln in Bantou village, combine the garden house of Gonghe County and the village of Taohua campus in Nangang Village to unite residents' centripetal force, cultivate residents' sense of participation, and use local characteristic industries to promote local economic development, as shown in "Table V". 
TABLE V. ANALYSIS OF BANTOU COMMUNITY CONSTRUCTION

\begin{tabular}{|c|c|c|c|c|}
\hline $\begin{array}{l}\text { The name of } \\
\text { community }\end{array}$ & Motivation & Resources & problems & solution \\
\hline $\begin{array}{l}\text { Bantou } \\
\text { Community }\end{array}$ & $\begin{array}{l}\text { regeneration of } \\
\text { historical } \\
\text { memory } \\
\text { activates } \\
\text { community }\end{array}$ & $\begin{array}{l}\text { 1.Five-point railway; } \\
\text { 2.Traditional craft } \\
\text { industries such as } \\
\text { Jiaozhi pottery and } \\
\text { shearing art; } \\
\text { 3. Rural Regeneration } \\
\text { Promotion } \\
\text { Association; }\end{array}$ & $\begin{array}{l}\text { 1.Low participation of } \\
\text { residents; } \\
\text { 2.Poor communication } \\
\text { between organizations; } \\
\text { 3.Insufficient cultural } \\
\text { creativity; }\end{array}$ & $\begin{array}{l}\text { 1.Taking the art community and } \\
\text { historical memory as the main } \\
\text { line; } \\
\text { 2.Building the station park; } \\
\text { 3.Development of Jiaozhi } \\
\text { pottery and bond craft; } \\
\text { 4.local cultural relics hall of top } \\
\text { vegetable garden; }\end{array}$ \\
\hline
\end{tabular}

\section{B. Analysis of Typical Cases of Community Construction in Fujian Province \\ 1) Fuzhou City - Three Lanes and Seven Alleys:} Located in the center of Fuzhou, Three Lanes and Seven Alleys is the inheritance of Fuzhou's traditional commercial culture. It is the abbreviation of ten alleys that are located from north to south on both sides of Nanhou Street in Fuzhou. Three pieces to the west are called "lanes", while the seven to the east are called "alleys"; "three lanes" are Yijin Lane, Wenru Lane, Guanglu Lane; "seven alleys" are Yangqiao Alley, Langguan Alley, Anmin Alley, Huang Alley, Ta Alley, Gong Alley and Jibi Alley [4]. Three Lanes and Seven Alleys, one of China's top ten historical and cultural streets, carries Fuzhou's rich historical information, strong cultural atmosphere and unique folk customs. It is also a national key cultural relics protection unit with immeasurable historical. cultural, artistic and social value.

In 1992, Fuzhou City reached an agreement with Hong Kong Changjiang Industrial Co., Ltd. on the project of joint protection and transformation of the region. In 1993, the two parties signed a cooperation agreement to officially launch the protection and reconstruction project of Three Lanes and
Seven Alleys, but the block pattern and cultural relics suffered serious damage due to the transformation process. Afterwards, it was forced to stop at the appeal of the general public and people of insight, but it also stimulated the public's consensus on the protection of Three Lanes and Seven Alleys Historic District; in 2005, "Protection and Development leading group of Three Lanes and Seven Alleys in Fuzhou" is established to carry out various transformation work successively; in 2006, the Three Lanes and Seven Alleys Protection and Restoration Project Management Committee was established, and the comprehensive repair and protection of Three Lanes and Seven Alleys was started. The government spent nearly 4 billion yuan to focus on clearing the history garbage of lanes and alleys, which completely changed the dilapidation of housing in lanes and alleys, population density, and poor sanitation, and re-plated the glorious history of Three Lanes and Seven Alleys. Three Lanes and Seven Alleys strives to build a cultural tourism brand and develop tourism industry, exhibition industry, creative industry, film industry and museum industry, to give play to cultural brand through linkage of multiple industries and radiate and drive the development of surrounding cultural industries, as shown in "Table VI" .

TABLE VI. ANALYSIS OF COMMUNity CONSTRUCTION IN THREE LANES AND SEVEN ALLEYS

\begin{tabular}{|c|c|c|c|c|}
\hline $\begin{array}{l}\text { The name of } \\
\text { community }\end{array}$ & Motivation & Resources & Problems & Solution \\
\hline $\begin{array}{ll}\text { Three } & \text { Lanes } \\
\text { and } & \text { Seven } \\
\text { Alleys } & \end{array}$ & $\begin{array}{l}\text { Economic } \\
\text { development } \\
\text { and protection } \\
\text { of historical and } \\
\text { cultural heritage }\end{array}$ & $\begin{array}{l}\text { 1.Rich natural landscape } \\
\text { and human heritage; } \\
\text { 2.Rich material culture } \\
\text { tourism resources and } \\
\text { non-material form } \\
\text { cultural tourism } \\
\text { resources; }\end{array}$ & $\begin{array}{l}\text { 1.issue on housing property } \\
\text { rights; } \\
2 . \text { Theory is greater than } \\
\text { practice; } \\
\text { 3. Funding issues; } \\
\text { 4.How to correctly handle the } \\
\text { relationship between } \\
\text { development and protection; } \\
\text { 5.Sustainable development } \\
\text { problem; }\end{array}$ & $\begin{array}{l}\text { 1."Microcirculation" } \\
\text { transformation mode; } \\
\text { 2. Create a cultural tourism } \\
\text { brand; } \\
\text { 3.assistance of cultural } \\
\text { creaticity; } \\
\text { 4.People-oriented; } \\
\text { 5.linkage of multiple } \\
\text { industries; }\end{array}$ \\
\hline
\end{tabular}

\section{2) Xiamen City - Zeng Cuo An Community: Zeng Cuo} An belongs to the Pearl Bay administrative community of Binhai Street in Siming District of Xiamen City, with a good location. From the construction in Yuan Dynasty community to the present, it has experienced the transformation of the three stages of the bridge villagefishing village-urban community. In the 1990s, Zeng Cuo An was still an original fishing village in southern Fujian. Due to the low rent, large creative space and good creative environment, it attracted some sculpture artists who brought a literary atmosphere to Zeng Cuo An. The gathering of a large number of art lovers has promoted the development of the community. In 2007, Xiamen Municipal Government will include Zeng Cuo An into the scope of urban transformation. In 2013, the beautiful Xiamen strategy listed Zeng Cuo An as a pilot in the city village, responding to the "Beautiful Xiamen Joint Creation" initiative, and concentrated community awareness to carry out 
community's common governance. It changed from a quiet small fishing village to a cultural village, forming a new model of community governance.

The community construction of Zeng Cuo An takes the form of government guidance and independent participation of residents to promote the self-management of multiple entities such as merchants, owners and tourists; changes the previous practice of "demolition and reconstruction", excavates local culture and builds Zeng Cuo An Village History Museum to retain the essence of Minnan culture; through the "holistic planning, organic renewal, community re-engineering" approach, it not only protects the historical features of the original ecological fishing village, but also injects open and diverse creative new functions; from the perspective of general goal, it contributes to the shaping and promotion of the fishing village brand; starting from small perspective, it gives the sincerest warmth and most romantic memories to domestic and foreign tourists as shown in "Table VII".

TABLE VII. ANALysis ON The COMMUNity CONSTRUCTION OF ZENG CuO AN

\begin{tabular}{|c|c|c|c|c|}
\hline $\begin{array}{l}\text { The name of } \\
\text { community }\end{array}$ & Motivation & Resources & problems & solution \\
\hline $\begin{array}{l}\text { Zeng } \\
\text { An }\end{array}$ & $\begin{array}{l}\text { fast } \\
\text { development of } \\
\text { urbanization } \\
\text {. }\end{array}$ & $\begin{array}{l}\text { 1.Excellent geographical } \\
\text { location; } \\
\text { 2.Traditional fishing } \\
\text { villages; } \\
\text { 3.Hometown of overseas } \\
\text { Chinese; } \\
\text { 4.Art lovers bring } \\
\text { "ambience of literature } \\
\text { and art"; }\end{array}$ & 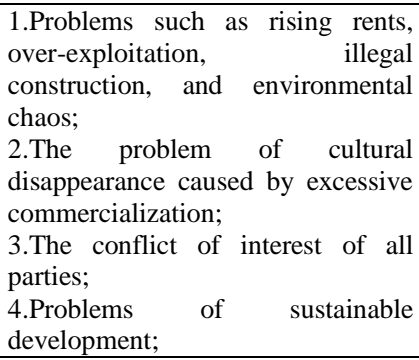 & $\begin{array}{l}\text { 1.Infrastructure } \\
\text { transformation; } \\
\text { 2.Establish a community } \\
\text { self-government system; } \\
\text { 3.Build a shared } \\
\text { governance platform } \\
\text { under the community- } \\
\text { building model; }\end{array}$ \\
\hline
\end{tabular}

3) Quanzhou City - 5 community construction pilots: Located in the southeastern part of Fujian Province, Quanzhou is the closest city to Taiwan in mainland China. In recent years, Quanzhou Municipal Government has actively promoted social governance innovation. In 2017, "Quanzhou City Management Improvement Action Plan" was launched, and community construction was included in one of the seven promotion projects. The City Management Office and the Municipal Finance Bureau formulated the "The Interim Measures for the Management of the Use of Funds for Quanzhou Community Construction Special Project", and "Community Construction" pilots are carried out in 5 communities led by the Municipal Management Office, namely Huaxin Community in Kaiyuan Street of Licheng District, Longling Community in Jinlong Street of Licheng District, Songlin Community in Donghu Street of Fengze District, Baoxiu plot of Baoshan Community in
Donghai Street of Fengze district and Wanfu Community in Wan'an Street of Luojiang District to promote community self-governance and co-administration and build a platform for co-planning, co-construction, co-management and sharing. The construction work starts from the community itself. Among them, the positioning of Huaxin community is the quiet and elegant community and poetic homeland, creating cultural products; Longling community focuses on cultural tourism, integrating red, green and local culture; Songlin community creates a community space of quality life and wisdom sharing and develops smart community APP; Baoxiu community creates a new home of peace and enjoyment, and create a modern life through "trinity"; Wanfu community mainly creates blessed and safe community, develops design business services and network management promotion platform to serve local residents as shown in "Table VIII".

TABLE VIII. ANALYSIS OF THE CONSTRUCTION OF FIVE PILOT COMMUNITIES IN QUANZHOU

\begin{tabular}{|c|c|c|c|c|}
\hline $\begin{array}{l}\text { The name of } \\
\text { community }\end{array}$ & Motivation & Resources & Problems & Solution \\
\hline $\begin{array}{l}\text { 1.Huaxin } \\
\text { Community } \\
\text { 2.Longling } \\
\text { Community } \\
\text { 3.Songlin } \\
\text { Community } \\
\text { 4.Baoxiu } \\
\text { Community } \\
\text { 5.Wanfu } \\
\text { Community }\end{array}$ & $\begin{array}{l}\text { The need for } \\
\text { urbanization } \\
\text { development }\end{array}$ & $\begin{array}{l}\text { 1.China's first luxury } \\
\text { villa area for returned } \\
\text { overseas Chinese; } \\
\text { 2.Traditional } \\
\text { revolutionary bases; } \\
\text { 3.Long history and } \\
\text { culture; } \\
\text { 4.resettlement } \\
\text { residential area; } \\
\text { 5. Business prosperity; }\end{array}$ & $\begin{array}{l}\text { 1.The interests of all parties; } \\
\text { 2.Red tourism products need to be } \\
\text { enriched and upgraded; } \\
\text { 3.The living space is messy; } \\
\text { 4.There is no community } \\
\text { neighborhood basis and cultural } \\
\text { deposits; } \\
\text { 5.There are many migrant } \\
\text { populations and it is difficult to } \\
\text { manage; }\end{array}$ & $\begin{array}{l}\text { 1.Quality and beautiful } \\
\text { villas in city and poetic } \\
\text { gardens; } \\
\text { 2.Right place for Red } \\
\text { tourism and keeping health; } \\
\text { 3.gentle and elegant } \\
\text { homeland; } \\
\text { 4.harmonious and happy } \\
\text { community and cheerful } \\
\text { homeland; } \\
\text { 5.Blessed people and safe } \\
\text { community; }\end{array}$ \\
\hline
\end{tabular}




\section{COMPARATIVE ANALYSIS OF THE CONSTRUCTION MODELS OF FUJIAN AND TAIWAN COMMUNITIES}

\section{A. The Model of Community Construction of Taiwan}

The community construction in Taiwan is mainly influenced by Japanese towns, British community buildings and American community design. From focusing on the people's livelihood and economic and social development of rural communities, the government department formulates overall planning and adopts unified models and steps. The resources are invested from the top to bottom, and they are carried out step by step by administrative means. Then they are committed to fostering the autonomy and participation awareness of the community residents, and gradually develop it into a bottom-up and point-to-face community identity system. [5]In addition, experts "counseling groups", NGO organizations, NPO organizations and institutions of higher learning provide technical, financial and information support to create continuous "resources" for communities in Taiwan. The process and content of the construction is divided into five parts: first, the re-creation of local culture; second, the participation of all residents; third, the mutual help and friendship; fourth, the innovation and promotion of the value of community resources; fifth, the symbiosis between man and nature [6].

\section{B. Exploration and Reflection on the Community Construction in Fujian}

The community construction in Fujian Province is still in the exploratory stage, and there is no clear construction pattern. However, local governments at all levels are actively exploring the construction strategies suitable for the development of the region to solve the difficulties and contradictions encountered in the transformation of social development. The community construction in Fujian Province is mainly based on the government-driven type. To solve the problem of grassroots social governance, it starts from the city. Usually, the government selects the community as the pilot for construction. According to the needs and plans of different communities, the corresponding resources are invested. Then planning and deployment is made from top to bottom, and the main function of community participants and implementing party is performing government affairs. Although some college design elites are also keen to participate in public discussions, the release of a series of incentive policies such as "productive services, sustainable design, and service design" also reflects the strategic thinking of national governors. However, in essence, designers can play a very limited role in community transformation and innovation practice. In the original complex relationship, the methods and ways for designers to participate in social and community innovation practice are worth pondering [7].

\section{Analysis of the Similarities and Differences Between Communities in Fujian and Taiwan}

Fujian and Taiwan have a common cultural tradition. In the community construction, Taiwan and mainland both reflect the government's administrative power leading the grassroots society construction, and emphasize the development of the community and the residents' selfgovernance. The result is usually hardware superior to software. The biggest difference between social governance in Taiwan and mainland is reflected in the development model and path of the community: the community construction in Taiwan emphasizes the community standard, and the government mainly plays an indirect guiding role, which presents a form of multi-dimensional cooperation between the government and the resources of all parties. The community governance in Fujian Province is the manifestation of national will. The government monopolizes the main resources and the community is basically a unified organizational form with low autonomy. This is related to the political and social background of Taiwan and mainland and the specific problems presented in the community as shown in "Fig. 2".

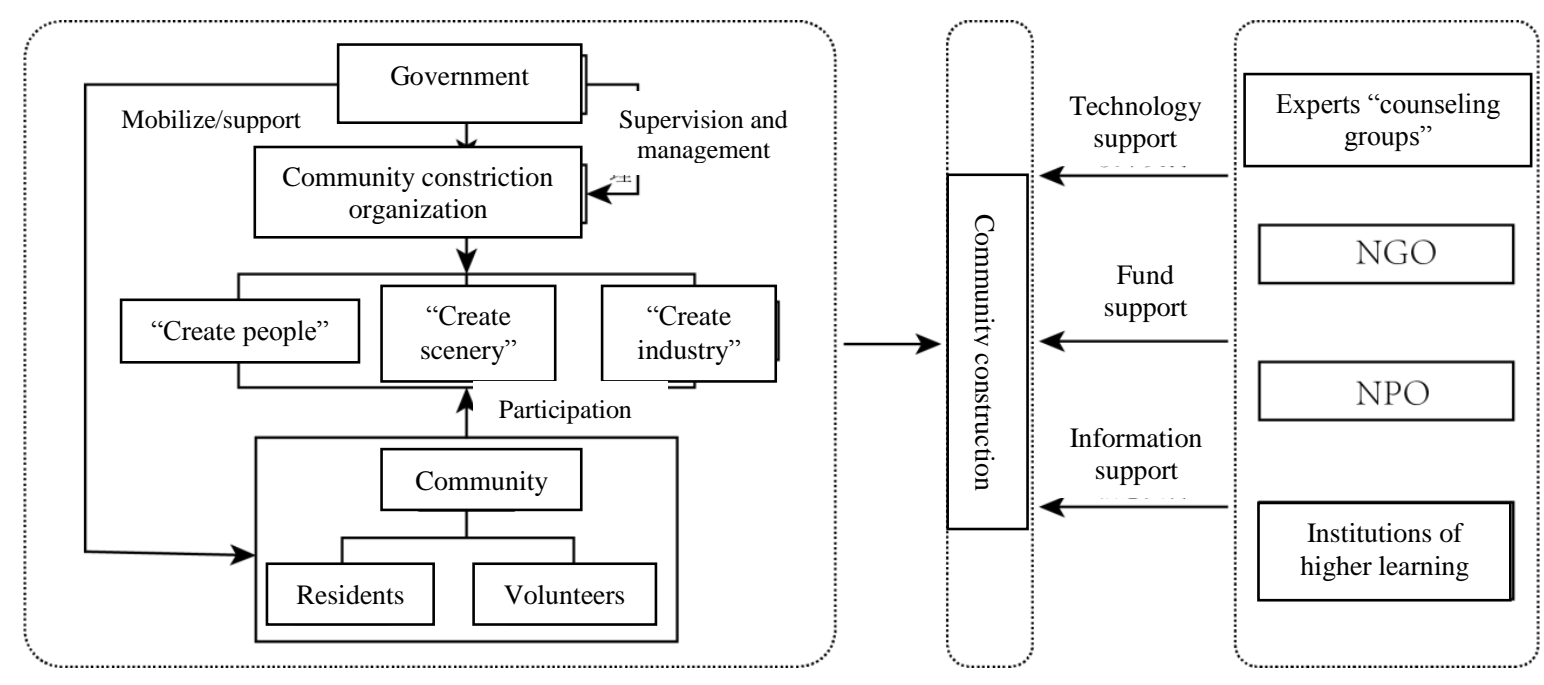

Fig. 2. Community Construction Model in Taiwan. 


\section{THE ENLIGHTENMENT AND THINKING OF THE COMPARISON BETWEEN COMMUNITY CONSTRUCTION IN FUJIAN AND TAIWAN}

\section{A. Up and down Linkage and People-oriented}

In the process of community construction, it is usually organized by relevant government departments, with community residents participating, and designers planning and designing. This is often effective in the initial stage of community construction since the government acts as a positive advertiser and uses its own characteristics to integrate resources. However, organizers are often not all users. How to promote social innovation with the internal vision and needs of "residents in the local area" requires organizers to examine their working methods from the perspective of local residents.

The construction of Fujian community is basically carried out in the mode of "pilot community". The selection of pilot communities is often determined by government departments and experts from the overall perspective. It is easy to cause the low enthusiasm of residents for participating in community construction. Therefore, the government departments should fully understand the real needs of the community residents, adopt the planning ideas of linkage between "upper" and "down", transform from the manager to the co-management of government and residents, from the resident' participation to the residents as the main body, and plan with the residents to participate together. The government acts as the initiator, advertiser, organizer, supporter and guider, instead of exclusively controlling the community affairs, as shown in "Fig. 3".

\section{B. Single Community and Diversified Development}

"Single" refers to a single community resource industry, and "diversity" is to integrate multiple ideas into a single community industry to give the industry multiple vitalities. "Single community and diversified development" is the solution to the needs of diversified markets.

From the development experience of community construction in Taiwan for many years, it can be seen that by adding accumulated experience to multiple ideas, a single community can be developed to a local community culture industry with local characteristics. And then we can manage by cultural creative design, which will promote the development of the community economy when improving the quality of the community. It not only has commonalities, but also highlights the characteristics of each community. It is based on reality, diversified and differentiated development, which is also what we need to focus on and draw lessons from.

\section{Intervention of Design and Sustainable Development}

The community construction in Taiwan has lasted for more than 20 years since 1996 . The community construction in Japan has lasted for more than 40 year since 1976. The community construction in these areas is not only the construction or improvement of simple infrastructure; they look on each process of community development with continuous, uninterrupted, and developmental perspective.

The urbanization process continues to accelerate, and the problems facing the community are constantly changing. The problems faced in the initial stage of community construction are usually the backward infrastructure and the deterioration of the ecological environment. Nowadays, there are many problems such as excessive commercialization, the disappearance of community culture and the alienation of neighborhoods. Therefore, an interdisciplinary innovative design intervention is needed. From understanding objects, defining requirements to creatively solving community problems, designers tend to observe object problems and potential needs more than other professions, and use different design practices to solve them, which can get the recognition of community residents more easily. In many complex issues, design intervention is often the key to solving the problem of sustainable development. 


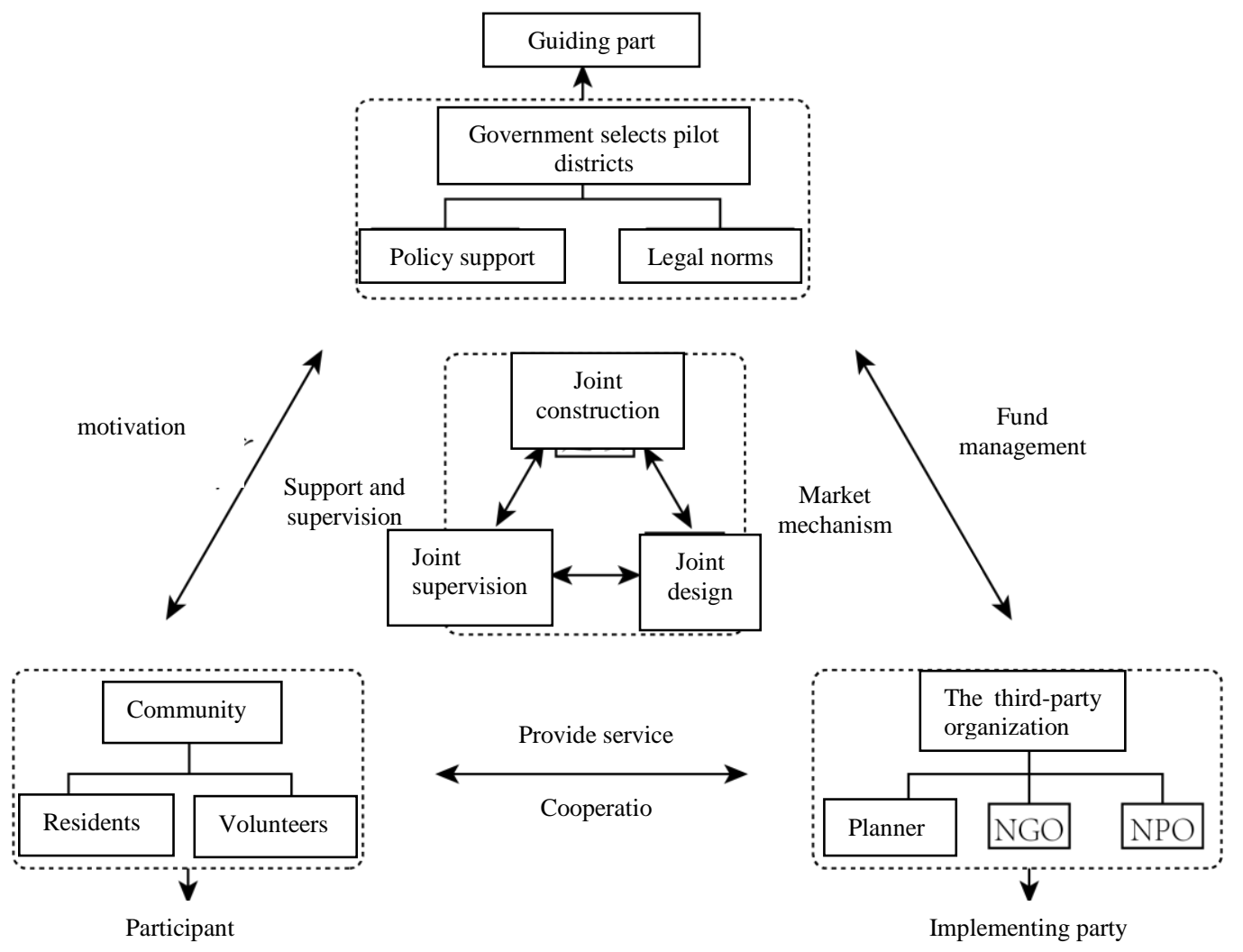

Fig. 3. Community Construction Model of Fujian Province.

\section{CONCLUSION}

In summary, Fujian and Taiwan share the same roots. Community construction in Fujian faces a similar cultural background and environment as that in Taiwan. The community construction in Taiwan precedes that in mainland, so its successful and failing cases and experiences has certain reference value for community building in Fujian and even other places in mainland. However, it should be noted that when learning the community construction in Taiwan, communities in Fujian should pay more attention to some unfulfilled problems that the Taiwan communities still face. At the same time, it is necessary to respect China's cultural traditions and realistic institutional constraints, and think from a sociological perspective to really let the design intervene in the community construction, and realize the community construction mode of democratic participation, interest coordination, cultural identity, beautiful environment and sustainable development.

\section{REFERENCES}

[1] Zhu Dongliang, Gao Yang. The practice and enlightenment of Fujian's innovative social governance[J]. Southeast Academic Research, 2015, No. 2.

[2] Jiang Yixian, Wang Bing'an. Analysis of legendary cultural creativity and rural community construction model—taking Taiwan Monster Village as an example[J], Journal of Fuzhou University(Philosophy and Social Sciences), 2015, No. 2 (Total No. 126).

[3] Gou Minxin. "Exploration into the construction strategy of rural communities in Taiwan" [D]. Southwest University, 2017: 5.
[4] Bai Dingguo. "2013: Report on cultural development of Fujian and Taiwan" [M]. Guangzhou: World Book Publishing Guangdong Co., Ltd., 2013.

[5] Guo Shengli, Chen Zhujun. A comparative study of cross-strait community governance and change [J]. Journal of Nanchang University(Humanities and Social Sciences), Vol. 44, No. 4, July 2013.

[6] Weng Xude, Miyazaki. "The concept of community construction" [M]. Nantou: Taiwan research Institute of Handicrafts, 1996, 22.

[7] Ji Tie. "Community research and social innovation design", [M]. Changsha: Hunan University Press, 2017.11, P4. 